\title{
Performance Appraisal and Employee Engagement: Does Tenure Matter? Evidence from South-West Nigeria
}

\author{
Kolawole Sunday Ajibola ${ }^{1^{*}}$, Elegwa Mukulu${ }^{2}$ and Alice Simiyu ${ }^{2}$
}

1 Lecturer, Department of Human Resource Development, Osun State University, Okuku Campus, Osun State, Nigeria

2 College of Human Resource Development, Jomo Kenyatta University of Agriculture and Technology, Kenya.

* Corresponding author ksajibola@ gmail.com)

Received: $O 1$ Nov, 2019 Revised: 30 Nov, 2019 Accepted: $26 \mathrm{Dec}, 2019$ Published: 28 Jan, 2020

How to cite this paper: Ajibola, K. S., Mukulu, E., Simiyu, A. (2019). Performance appraisal and employee engagement: Does tenure matters? Evidence from South-West Nigeria. Quest Journal of Management and Social Sciences, 1(2), 146-164.

Copyright (C) 2019 by authors and Quest Journal of Management and Social Sciences

This work is licensed under a Creative Commons Attribution-NonCommercial-NoDerivatives 4.0 International License.

https://creativecommons.org/licenses/ by-nc-nd/4.0/

\begin{abstract}
Background: The level of employee engagement globally is declining. Evidences points to low level of employee engagement in Nigeria. In this study, performance appraisal and performance appraisal feedback are hypothesized as factors that increase the level of employee engagement.
\end{abstract}

Objective: The objective of the study was to investigate the influence of performance appraisal and performance appraisal feedback on the employee engagement among workers in South-West Nigeria.

Methods: The study adopted descriptive research approach. Respondents were sampled from employees of one State University, wire industries, and oil and gas sector in Osun State capital, Nigeria. Stratified and simple random sampling techniques were used to select 250 respondents. The questionnaire was used for data collection. Only 139 (54.51\%) questionnaires were found useful for the analysis. Descriptive statistics, correlation and regression analyses were used for the data analysis.

Results: The study found out that performance appraisal had positive significant influence on employee engagement but the relationship between performance appraisal feedback and employee engagement was found to be statistically insignificant. Tenure was found to moderate the influence on the relationships.

Conclusions: Based on the findings of the study, the study concluded that employee tenure was an important moderator in the relationship between performance appraisal, performance appraisal feedback and employee engagement.

Implications: The implication of the findings of this study was that employee characteristics are important factors for the consideration of Human resource practitioners for organization effectiveness and productivity.

Recommendations: The paper recommended that HR managers should pay more attention to the employee metrics in implementing HR policies.

Originality: This article is original article and no potential conflicts of interest with respect to the research, authorship and or publication of this article. No financial support was received for the research, authorship and or publication of this article.

Keywords: employee engagement, HR analytics, HR metrics, performance appraisal feedback, performance appraisal.

Paper Type: Research paper

JEL Classification: $\mathrm{O}_{15}, \mathrm{M} 12, \mathrm{~J} 24$ 


\section{Introduction}

Performance appraisal is one of the core functions of human resource development (Hughes, 2019, p. 79). Performance appraisal "means evaluating an employee's current and/or past performance relative to his or her performance standards" (Dessler, 2013, p. 274). It is a "formal system of reviewing and evaluation of individual or team task performance"(Mondy and Martocchio, 2016, p.188; Torrington et al., 2017).The performance appraisal involves three-step performance appraisal processes which are: "setting work standards, assessing the employee's actual performance relative to those standards, and providing feedback to the employee with the aim of helping him or her to eliminate performance deficiencies or to continue to perform above par"(Dessler, 2013, p. 274). In the whole process of performance appraisal, the feedback is important because of the employees' perception, and emotion before, during and after the exercise. Wilkinson, Redman, and Dundon (2017) opined that organizations goals and objectives cannot be achieved devoid of human resource contributions. The human resource efforts towards the organizational effectiveness are evaluated to ensure that the set goals and objectives are met at the right time with the desired results. The employee performance appraisal is done as part of the performance management system of an organization. Meanwhile, the perception of employees is important in arriving at the point of whether or not the process of performance appraisal is procedurally correct, just, ethical and or fair (Hughes, 2019, p.82). This, of course, has several outcomes such as organization performance, employee commitment, employee job satisfaction, employee effectiveness, employee turnover intention, and employee engagement among others.

Previous studies on employee engagement point to the organizations' success dependency on the level of employees' engagement. For instance, Daniels (2016); Jung, Yoon, and Yoon (2018) reported that the association between the human resource management functions such as performance appraisal and employee engagement is significant in organizational success stories. In the words of Shuck, Reio, and Rocco (2011), human resource management practices are capable of significantly improving the level of employee engagement, "could create a compelling competitive advantage for organizations across the globe"(Shuck, Reio, \& Rocco, 2011). For this development and trend in the field of employee engagement, it has been suggested that human resource management need "to go beyond the traditional roles and become a strategic partner in businesses, focusing attention on engaging employees at deeper levels"(Bhowal \& Saini, 2019). The downward trend in employee engagement had been noticed and reported globally(Nel \& Linde, 2019).The observation further confirmed the survey reports by Gallup (2018) who earlier reported that the global level of employee engagement has been nose-diving since 2015 until 2017 when it picked up again (see Figure 1). One of those factors responsible for the increase in employee turnover and a decrease in the level of employee engagement according to Hassan (2007, p. 435) in Hughes (2019) was performance appraisal. 
Figure 1: Global Trends in Employee Engagement

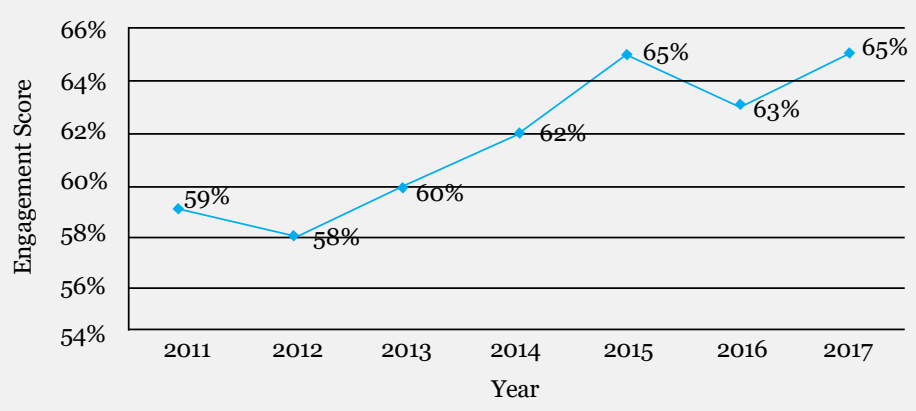

Source: Gallup (2018)

Bhowal and Saini (2019) had considered employee engagement as the "cornerstone upon which rests a number of positive business outcomes such as productivity, improved bottom lines, growth, customer satisfaction, employee retention and safety." This assertion is verified by the various empirical studies which have established links between human resource maintenance practices such as performance appraisal and employee engagement globally. Such linkages include study among Australian and US nurses that reported a significant influence of perceived organizational support (POS), leadership, and teamwork on employee engagement (Brunetto et al., 2013). Likewise in the UK, where it was found out that there is a positive significant relationship between perceived human resource management practices and employee engagement(Alfes, Truss, Soane, Rees, \& Gatenby, 2013).

The proper alignment of the organization's performance appraisal is essential to the achievement of business goals and objectives. When human resource practices such as performance management are aligned with the business objectives of the organization, the result is always positive. The outcomes of such are high employee performance, high employee job satisfaction, low employee turnover and an increase in the level of employee engagement. Studies have demonstrated that performance appraisal increases the level of employee engagement significantly(Shin, Jeong, \& Bae, 2016).

Inadequate human resource practices in Nigerian foods and beverages sectors manifested in high employee turnover, incessant industrial actions, poor performance and low level of employee engagement. The performance appraisal as one of the core human resource management functions in foods and beverages sector in Nigeria has been described as poor and plagued with a myriad of unethical practices (Fajana, 2009; Izuogu, 2015). The increasing rate of employee turnover and decreasing level of employee engagement is considered as results of the employees' perception of performance appraisal system being unfair and/ or unethical with poor or lack of performance appraisal feedback (Hughes, 2019).

Continuation of such trend will only increase the employee turnover intention and the organization performance will be nose-diving and these trends eventually will have a grave impact on the national economy and can lead to human capital flight away from the country. Previous studies investigated the impact of performance appraisal on organizational produc- 
tivity, job satisfaction, employee productivity but without explaining the role of performance appraisal mechanism on employee engagement (Kihama \& Wainaina, 2019). Given this, therefore, this study was undertaken to fill the gap. Consequent upon the foregoing, the study was to investigate the influence of performance appraisal feedback mechanism on employee engagement among employees of oil and gas, wire industries, and tertiary institution.

The remaining part of this paper is organized into three sections. The next section will represent overall methodology of the study, where materials and methods will be discussed. Then, the results and the discussion of key issues will be presented, followed by concluding remarks.

\section{Review of Literature}

\section{Theoretical Review}

\section{Expectancy Theory}

The proponent of the expectancy theory (ET) was Victor Vroomin (1964). The ET states that people will tend to do more when they are aware of what they will get at the end in relations to their effort. The underlining factor of this theory was performance management and feedback (Salaman, Storey, \& Billsberry, 2005). Its application has a direct impact on work settings (Lunenburg, 2011). Armstrong and Taylor (2014) surmise that the level of motivation is high when people are aware of what to do to have their rewards. This means employees will perform better if the feedbacks of their performance appraisal are given to them.

The concept of ET originated from valency-instrumentality-expectancy (VIE) theory propounded in Vroom (1964). It is goal-oriented. The beliefs of expectancy theory concerning valency state that it is emotional orientation that employees have towards the performance appraisal process and outcome. Expectancy belief states that different employees with different expectations and levels of confidence about what they are capable of doing. The instrumentality is the perception held by employees on whether or not they will receive what they have desired (Vroom, 1964).

In the context of this study, if the performance appraisal of employees is done with favouritism and perceived by the employees as a process laden with injustice and inequity, then the level of employee engagement cannot improve but the morale will be low and this will result to employee disengagement.

When this is applied to Nigerian food and beverages sector work settings, it helps to explain employees' behaviour to performance appraisal process and mechanism. The perception of the employee on process and feedback of performance appraisal has a significant impact on the level of engagement.

\section{Social Categorization Theory}

Social categorization theory (SCT) was an offshoot of social identity theory which stated that self-concept is a product of employee perception. The social identity theory (SIT) was propounded by Henri Tajfel and John Turner with limited scope (Turner \& Reynolds, 2010). The theory explains that the perception of people on the social category of people who are along 
with certain social strata/factors such as gender, age, race, occupation, length of service, and so on as a group.

The theory explains the rationale behind the feelings of an employee being a member of a group (in-group) and not of the other group (out-group). The theory is helpful to explain the behaviour of employee socially classified along with demographics such as gender, age, tenure, and so on in the workplace. Critics of this theory have pointed to the problem of stereotyping which the theory failed to explain because of its explanations that other members who belong to out-group are seen by the in-group as less trustworthy, not that honest and uncooperative as in-group

\section{Empirical Review}

\section{Performance Appraisal, Feedback and Employee Engagement}

In Bahrain, Alzyoud (2018) investigated the influence of employee communication, employee development, reward, and recognition on employee work engagement. The sample for the study was 151 staff members from the manufacturing sector. The study used correlation and regression analysis and found out that employee communication, employee development, reward, and recognition significantly influence employee engagement in the manufacturing sector of Bahrain (Alzyoud, 2018). The study was carried out in an environment different from that of Nigeria.

A study carried out in China among 298 employees and 54 supervisors found out that supervisor perceptions of HR practices and work engagement are positive and significant when supervisor and subordinate share the same 'hukuo' status (Li \& Frenkel, 2017). The sector in which the study was conducted was not clear. Empirical findings within the current streams of HRM research have so far also been so largely inconclusive(Alfes et al., 2013). Another study in Kenya was on performance appraisal feedback and employee productivity in water and sewage companies in Kiambu County of Kenya. The study had 242 respondents and used correlation and regression analyses with the aid of SPSS. The study found out that performance feedback had a positive significant relationship on employee productivity (Kihama \& Wainaina, 2019). The findings of the study swing to both sides with no specific direction. Hence, the following hypotheses were formulated:

$\mathbf{H}_{\mathbf{o}}$ : Performance appraisal has no significant influence on employee engagement among employees of oil and gas, wire industries, and tertiary institution in South-West Nigeria.

$\mathbf{H}_{\mathbf{o} 2}$ : Performance appraisal feedback mechanism has no significant influence on employee engagement among employees of oil and gas, wire industries, and tertiary institution in South-West Nigeria.

\section{Employee Tenure and Employee Engagement}

The moderating influence of employee tenure on the relationship of performance appraisal feedback and other outcomes has been established even though conflicting. In a study carried out in India, the results of the study found significant differences in the work engagement level of employees concerning age, year of work experience, and employee position except 
for gender(Rana \& Chopra, 2019).

A study conducted in Pakistan reported no significant association between job period and affective commitment(Mustafa et al., 2017). However, a statistically significant difference in employee tenure was reported in another study(Menguc et al., 2017). With the conflicting findings, this study was embarked upon to fill the gap. Hence, this study hypothesized as follow:

$\mathbf{H}_{\mathbf{o}}$ : Employee tenure do not significantly moderate the relationship between performance appraisal feedback mechanism and engagement employee engagement among employees of oil and gas, wire industries, and tertiary institution in South-West Nigeria

\section{Conceptual Framework}

The conceptual framework is developed to provide clear links of dependent and independent variables as they relate to each other in this research. It gives explanation on why a research is conducted in a certain way pictorially (Mugenda \& Mugenda, 2012). The conceptual framework of this study is based expectancy theory and social categorization theory. Performance appraisal, performance appraisal feedback forms the independent variables; employee tenure was used in the study as moderating variable and employee engagement as the dependent variable. The conceptual framework for the study is presented in Figure 2.

\section{Performance Appraisal and Performance Appraisal Feedback}

Performance appraisal according to Armstrong and Taylor(2014) is a "systematic process involving the agreement of performance expectations and the review of how those expectations have been met. Performance appraisal is one of the core functions of human resource development (Hughes, 2019, p. 79). Performance appraisal "means evaluating an employee's current and/or past performance relative to his or her performance standards" (Dessler, 2013, p. 274). It is a "formal system of review and evaluation of individual or team task performance" (Mondy and Martocchio, 2016, p.188; Torrington et al., 2017). The performance appraisal involves three-step performance appraisal processes i.e.,: "setting work standards, assessing

Figure 2: Conceptual Framework

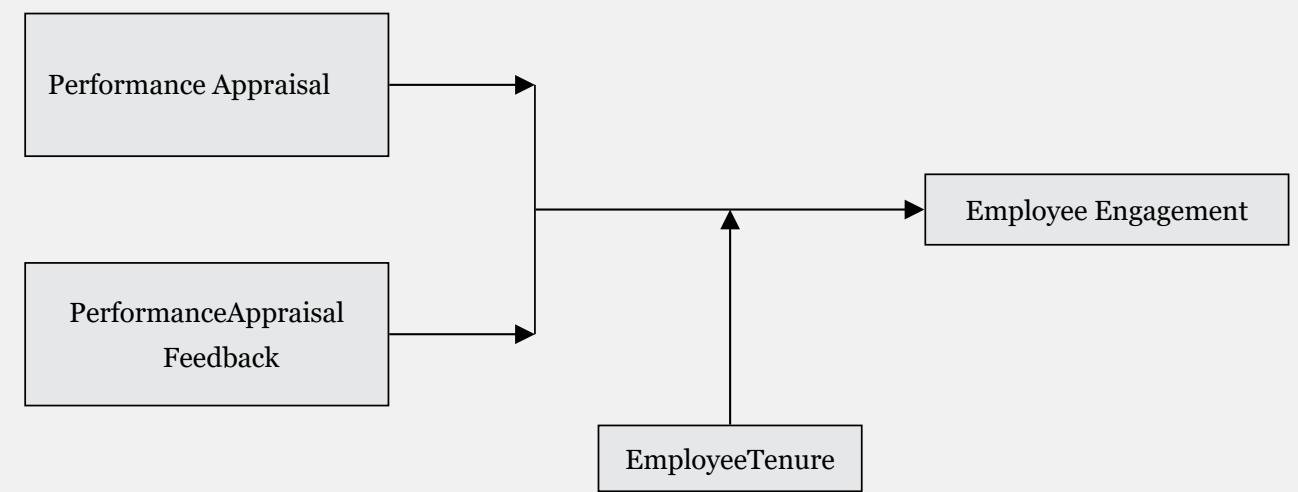

Independent Variables

Moderating Variables

Dependent Variables 
the employee's actual performance relative to those standards, and providing feedback to the employee with the aim of helping him or her to eliminate performance deficiencies or to continue to perform above par"(Dessler, 2013, p. 274)

Performance appraisal has three broad purposes: strategic, administrative, and developmental (Noe, Hollenbeck, Gerhart, \& Wright, 2016). As a process and practice, it sets a platform for employee recognition and rewarding excellence by aligning the individual employee accomplishment with the organizational mission, objectives, and vision. This study concentrated on a performance feedback mechanism. According to Brown and Redman (2017), "if employee regards their supervisor as credible, they are more like to accept the rating than when the supervisor is not a credible source" (Brown \& Redman, 2017). The performance appraisal feedback must be communicated to the employees.

There are several methods and techniques for measuring the performance of employees in organizations. They can be traditional or modern techniques. Traditional techniques include the straight ranking method, paired comparison method, graphic rating scales, forced description method, the checklist method, essay method, critical incidents, group appraisal, field review. Management by objectives (MBO), assessment centers, 360-degree appraisal, human asset accounting, balanced scorecard and behaviorally anchored rating scales (BARS) are considered as modern techniques(Brown \& Redman, 2017; Dessler, 2013; Mamoria \& Rao, 2014; Torrington et al., 2017).

The feedback mechanism is a system put in place by an employer to support employee for improved performance and increase employee engagement which had been considered as ethical (Hughes, 2019). Regular feedback to an employee is of benefit to both the organization and individual employee; it is quick and inexpensive to obtain (Mondy \& Martocchio, 2016). The aftermath of the failure to give performance feedback to employees after the performance appraisal leads to an increase in employee turnover intention. Hughes (2019, p. 82) reported that "many employees left the organizations because they believed that the performance appraisal process was unfair and or the rater had not rated them ethically or fair". Hence, performance appraisal feedback is important.

\section{Employee Tenure}

Moderators to the relationship between performance appraisal and employee engagement identified in the literature include sex (gender), race, tenure, and age (Laba \& Geldenhuys, 2016). Tenure is the length of service of employee or job period. This is the length of period employee have continuously been working for an organization. Studies have pointed out that it can moderate the relationship between HR functions and organization outcomes. Blessingwhite (2011) report indicated that the long-time employees that have spent 7 years and above with an organization tend to be more engaged than new employees(Blessingwhite, 2011). It has been reported that no significant association was observed between job period (tenure) and affective commitment (Mustafa, Bilal, Mahmood, \& Murtaza, 2017). However, a statistically significant difference in employee tenure was reported in another study(Menguc, Auh, Yeniaras, \& Katsikeas, 2017).

Studies have found out that engagement levels vary according to employee's age, tenure, seniority, occupation and employee's personality characteristics. If an employee perceives 
that no discrimination is meted out by the management based on demographics, there is the propensity for the level of engagement to rise. According to Menguc, Auh, Yeniaras, and Katsikeas(2017), employee-level factors such as demographics, self-efficacy and leadership moderated the relationship between HR practices and employee engagement(Menguc et al., 2017).

\section{Research Method}

\section{Research Design}

Descriptive research design using both quantitative and qualitative approaches was adopted for this study. The descriptive research design was considered suitable for the study because of its capability to give an accurate account of the characteristics of the event or real-life situation.

\section{Population, Sample and Sampling Techniques}

The target population of this study comprised employees from one State University, wire industries, and oil and gas sector in Osun State capital. The sample size for the study was determined by the use of Yemane (1965) sample size determination formula. With the use of stratified random sampling and simple random sampling techniques, 250 samples were selected.

\section{Data Collection Tool}

The questionnaire was used for data collection. The questionnaire was divided into three sections. Section A was designed to collect data on respondent's biographical information, section B was on performance appraisal and feedback and section C contained adopted and modified items from Utrecht Work Engagement Scale (UWES-9) on employee engagement developed by Schaufeli and Bakker (2006). A five-point Likert scale was used for most of the questions while open-ended questions were used in the biographical section and on the indicators to control biased responses from the respondents.

\section{Data Collection Technique}

Self-administered drop and pick questionnaires were used to collect the data from the randomly selected employees based on the sample size from the strata. This was backed up with follow-ups which assisted in achieving a high rate of response. Both middle-level managers and operational staff members were included in the study. They were targeted because they are the custodians of the data required for the study. However, top management was excluded from the study.

\section{Duration of the Study}

A total of 255 questionnaires were administered to 255 employees of wire industries, one State University and oil and gas sectors operating in the State capital of Osun State. The period of data collection was between February 2018 and April 2018.

\section{Data Analysis}

Data collected were analysed using the Statistical Package for Social Sciences version 22. All data collected were subjected to diagnostic tests to find out whether or not any of the assumptions of classical linear regression model were violated. Correlation analysis and regression 
model was used in the analysis of the data collected in the study. This model was considered appropriate because the study focused on establishing the relationship and moderating influence of variables under study.

\section{Data Analysis and Result}

\section{Gender Distribution of Respondents}

The majority of the respondents, 60.4\% (84) were male and 39.6\% (55) of the respondents were female. The results are presented in Table 1 . The ratio of male respondents to female respondents was about 3 to 2.A study reported a ratio of about 1 to 1 (Mugesani, 2018). This result implied that the responses were taken from both genders in the industry under study.

TABLE 1: Composition of Respondents by Gender

\begin{tabular}{|c|c|c|}
\hline Gender & Frequency & Percent \\
\hline Male & 84 & 60.4 \\
\hline Female & 55 & 39.6 \\
\hline Total & $\mathbf{1 3 9}$ & $\mathbf{1 0 0 . 0}$ \\
\hline
\end{tabular}

\section{Descriptive Analysis}

\section{Age of Respondents}

The study found out that $39.6 \%$ of the respondents' age was below 35 years, while the majority of the respondents' age was between 36 - 45 years age brackets and only 15.1\% of the respondents were older than 45 years as shown in Table 2. This indicated that the majority (45.3\%) of the respondents belonged to generations $\mathrm{X}$ and $84.9 \%$ of the respondents constituted generation $\mathrm{X}, \mathrm{Y}, \mathrm{Z}$ (the digital natives). This indicated that the majority of respondents for the study were from those generations.

TABLE 2: Age Distribution of Respondents

\begin{tabular}{|c|c|c|}
\hline Age & Frequency & Percent \\
\hline $18-25$ years & 9 & 6.5 \\
\hline $26-35$ years & 46 & 33.1 \\
\hline $36-45$ years & 63 & 45.3 \\
\hline $46-55$ years & 16 & 11.5 \\
\hline $56-65$ years & 5 & 3.6 \\
\hline Total & $\mathbf{1 3 9}$ & $\mathbf{1 0 0 . 0}$ \\
\hline
\end{tabular}

\section{Respondents' Tenure}

The results of the data collected on the length of continuous service with the organization (tenure) are presented in Table 3. It shows that $46.1 \%$ of the respondents served their organization continuously for a period between $\mathrm{o}-5$ years, $41.7 \%$ of the respondents served between $6-10$ years, and $12.2 \%$ between $11-15$ years.

From the results presented in Table3, majority (87.8\%) of the respondents in the study served their organizations for up to 10 years. However, only $12.2 \%$ of the respondents served 
their organizations beyond 10 years. This indicated that many of the employees were not employed for a long time. Another reason for this could be because of the respondents from one of the State universities that was part of this study began operation in 2007. Employee retention challenges may be another reason as well.

This finding makes the length of continuous service important to this study. Since the majority of the respondents were from generation $\mathrm{Y}$ and $\mathrm{Z}$. Generation $\mathrm{Y}$ grew up with access to computers, access to the Internet, with diversity, they are willing to learn, possess a high level of self-esteem (Noe, 2017). They are characterized as having low power distance, those that have an entrepreneurial spirit, like work flexibility, fun, want autonomy, and they are short term and fast achievers(Imperatori, 2017). This made tenure an important factor to look at whether or not it influences the relationship between performance appraisal feedback and employee engagement.

TABLE 3: Respondents' Tenure

\begin{tabular}{|c|c|c|}
\hline Years of Service & Frequency & Percent \\
\hline 0 -5 years & 64 & 46.1 \\
\hline $6-10$ years & 58 & 41.7 \\
\hline $11-15$ years & 17 & 12.2 \\
\hline Total & $\mathbf{1 3 9}$ & $\mathbf{1 0 o . 0}$ \\
\hline
\end{tabular}

\section{Level of Education of Respondents}

The results on the highest level of education of the respondents were presented in Table 4. It indicates that respondents with a Bachelor's degree and Higher National Diploma (HND) had the highest percentage of $54 \%$. This tally was followed by those respondents with an Ordinary National Diploma (OND). The results showed that $26.6 \%$ of the respondents had OND. Respondents with a Master's degree followed with a frequency of $14.4 \%$ and respondent with Ph.D. and NCE were $1.4 \%$. Respondents with professional qualifications were $3.6 \%$ of the respondents. From Table 4, about $70 \%$ of the respondents for this study had a first degree or higher, which indicates that the respondents for this study are educated.

TABLE 4: Level of Education of Respondents

\begin{tabular}{|l|c|c|}
\hline Education Qualification & Frequency & Percent \\
\hline Doctoral (Ph.D.) degree & 1 & 0.7 \\
\hline Master's degree & 20 & 14.4 \\
\hline Bachelor's degree/HND & 75 & 54 \\
\hline Professional qualification & 5 & 3.6 \\
\hline Ordinary National Diploma & 37 & 26.6 \\
\hline National Certificate of Education (NCE) & 1 & 0.7 \\
\hline Total & $\mathbf{1 3 9}$ & $\mathbf{1 0 0 . 0}$ \\
\hline
\end{tabular}

\section{Inferential Analysis}

Correlation Analysis between Construct Performance Appraisal, Performance Feedback, and Employee Engagement 
The study also sought to determine whether or not there is a statistical relationship between performance appraisal practice, performance feedback mechanism and engagement employee engagement among employees of oil and gas, wire industries, and tertiary institution in South-West Nigeria. Table 5 shows the Pearson's correlation coefficient between the performance appraisal and employee engagement being .244, p<0.05, two-tailed, tested at 95\% confidence level.

The results showed a positive and significant relationship between performance appraisal and employee engagement among employees of oil and gas, wire industries, and tertiary institution in South-West Nigeria. This shows that performance appraisal influenced employee engagement among employees of oil and gas, wire industries, and tertiary institution in South-West Nigeria. The implication of the findings of the study concurred with the findings of Jani and Balyan (2016) who found out that there was a positive significant relationship between performance appraisal and employee engagement.

The results also indicated that there was an insignificant positive relationship between performance appraisal feedback and employee engagement among employees of oil and gas, wire industries, and tertiary institution in South-West Nigeria. The Pearson's correlation coefficient was 0.156 and the p-value $=0.066$ which was greater the alpha value of 0.05 level of significance. This shows that performance appraisal feedback had a statistically insignificant relationship with employee engagement among employees of oil and gas, wire industries, and tertiary institution in South-West Nigeria. The implication of the findings of the study disagreed with the findings of Kihama and Wainaina (2019) who found out that there was a positive significant relationship between performance appraisal feedback and employee productivity.

TABLE 5:Pearson Correlation Coefficient between Performance Appraisal, Performance Appraisal Feedback Mechanism, and Employee Engagement

\begin{tabular}{|c|c|c|c|c|}
\hline \multicolumn{2}{|c|}{ Variable } & \multirow{2}{*}{$\begin{array}{c}\text { Performance } \\
\text { Appraisal } \\
1\end{array}$} & \multirow{2}{*}{$\begin{array}{c}\text { Performance } \\
\text { Appraisal } \\
\text { Feedback }\end{array}$} & \multirow{2}{*}{$\begin{array}{c}\text { Employee } \\
\text { Engagement }\end{array}$} \\
\hline \multirow{3}{*}{$\begin{array}{l}\text { Performance } \\
\text { Appraisal }\end{array}$} & Pearson Correlation & & & \\
\hline & Sig. (2-tailed) & & & \\
\hline & $\mathrm{N}$ & 139 & & \\
\hline \multirow{3}{*}{$\begin{array}{l}\text { Performance } \\
\text { Appraisal } \\
\text { Feedback } \\
\text { Mechanism }\end{array}$} & Pearson Correlation & .033 & 1 & \\
\hline & Sig. (2-tailed) & .704 & & \\
\hline & $\mathrm{N}$ & 139 & 139 & \\
\hline \multirow{3}{*}{$\begin{array}{l}\text { Employee } \\
\text { Engagement }\end{array}$} & Pearson Correlation & $.244^{* *}$ & .156 & 1 \\
\hline & Sig. (2-tailed) & .004 & .066 & \\
\hline & $\mathrm{N}$ & 139 & 139 & 139 \\
\hline
\end{tabular}

**. Correlation is significant at the 0.01 level (2-tailed).

Regression Analysis between Construct Performance Appraisal Practice and Employee Engagement

The second objective of the study was to determine the influence of performance appraisal on employee engagement among employees of oil and gas, wire industries, and tertiary in- 
stitution in South-West Nigeria. The regression analysis was conducted and the results are presented in Table 6 . The results showed the relationship $\mathrm{R}=.244$, which indicates a positive association between performance appraisal and employee engagement. Adjusted R-squared $=.060$ which indicated that $6 \%$ of the variation in the employee engagement can be explained by performance appraisal while the remaining can be explained by other variables

TABLE 6: Model Summary of Performance Appraisal

\begin{tabular}{|c|c|c|c|c|}
\hline Model & R & R Square & Adjusted R Square & Std. Error of the Estimate \\
\hline 1 & $.244^{\mathrm{a}}$ & .060 & .053 & .96994 \\
\hline
\end{tabular}

a. Predictors: (Constant), Performance Appraisal

The overall model significance of the study was presented in Table 7. The ANOVA results indicate that the regression model predicts the outcome variable statistically significantly well with $\mathrm{F}$ statistic of $\mathbf{8 . 6 8 6}$ which indicated that the overall model was significant at 95\% confidence level and the relationship was not just by chance. This was supported by a probability value of 0.004 which was less than alpha $=0.05$. This implied that the model applied could statistically and significantly predict the outcome variable. With p-value less than 0.05, it indicated that the goodness of fit for the regression model established between the independent and dependent variable. The study, therefore, rejected the null hypothesis, Ho1 at 95\% confidence interval and concluded that performance appraisal has a significant influence on the employee engagement among employees of oil and gas sector, wire industries, and tertiary institution in South-West Nigeria.

TABLE 7: ANOVA FOR PERFORMANCE APPRAISAL

\begin{tabular}{|c|c|c|c|c|c|c|}
\hline \multicolumn{2}{|c|}{ Indicator } & Sum of Squares & df & Mean Square & F & Sig. \\
\hline \multirow{3}{*}{1} & Regression & 8.171 & 1 & 8.171 & 8.686 & .004 \\
\cline { 2 - 9 } & Residual & 128.886 & 137 & .941 & & \\
\cline { 2 - 9 } & Total & $\mathbf{1 3 7 . 0 5 8}$ & $\mathbf{1 3 9}$ & & & \\
\end{tabular}

a. Dependent Variable: Employee Engagement

b. Predictors: (Constant), Performance Appraisal

The performance appraisal (PA) coefficients are presented in Table 8. The results show that performance appraisal contributes significantly to the model since the p-value was less than alpha $=0.05$. To test for the significance of performance appraisal, the regression coefficients $\left(\beta_{1}\right)$, the intercept ( $\beta o$ ), and the significance of the model were subjected to the t-test to test the null hypothesis that the coefficient is zero. The null hypothesis stated that $\beta$ (beta) $=0$, meaning that there is no significant influence of performance appraisal on employee engagement as the slope $\beta$ (beta) $=0$.

The $\mathrm{Y}=\beta \mathrm{O}+\beta_{1} \mathrm{X} 1+\varepsilon$ therefore became Employee Engagement $=1.374+0.258$ (Performance Appraisal). The results on the beta coefficient of the resulting model showed that the constant alpha $=1.374$ is significantly different from $\mathrm{o}$ since the $\mathrm{p}$-value $=0.000(\mathrm{p}<0.05)$. The coefficient $\beta=0.258$ was also significantly different from 0 with a $p$-value $=0.004$ which is less than 0.05. The findings suggested that one unit change in employee engagement would lead to 0.258 changes in oil and gas, wire industries, and tertiary institution in South-West Nigeria. 
TABLE 8:REGRESSION COEFFICIENTS OF PERFORMANCE APPRAISAL

\begin{tabular}{|c|c|c|c|c|c|}
\hline Model & $\beta_{\mathrm{i}}$ & Std. Error & Beta & t & Sig. \\
\hline $\begin{array}{c}\text { (Constant) } \\
\text { Performance Appraisal }\end{array}$ & 1.374 & .298 & & 4.606 & .000 \\
\cline { 2 - 6 } & .258 & .088 & .244 & 2.947 & .004 \\
\hline
\end{tabular}

Regression Analysis between Construct Performance Feedback and Employee Engagement The second objective of the study was to examine the influence of performance appraisal feedback on employee engagement in the oil and gas sector, wire industries, and tertiary institution in South-West Nigeria. The results of the regression analysis are presented in Table 9 showed the relationship $\mathrm{R}=.156$, which indicated a positive association between performance appraisal feedback and employee engagement. $\mathrm{R}$-squared $=.024$ indicated that $2.4 \%$ of the variability in employee engagement can be explained by performance appraisal feedback while the remaining can be explained by other variables

TABLE 9: Model Summary of Performance Appraisal Feedback

\begin{tabular}{|l|l|l|l|l|}
\hline Model & $\mathrm{R}$ & R Square & Adjusted R Square & Std. Error of the Estimate \\
\hline 1 & $.156^{\mathrm{a}}$ & .024 & .017 & .98793 \\
\hline
\end{tabular}

a. Predictors: (Constant), Performance Appraisal Feedback

The overall model significance was presented in Table 10. The overall model was insignificant at $95 \%$ confidence level with $\mathrm{p}>0.05$. The study, therefore, failed to reject the null hypothesis, Ho2 at 95\% confidence interval and concluded that performance appraisal feedback has no significant influence on the employee engagement in oil and gas, wire industries, and tertiary institution in South-West Nigeria as found out by the study.

TABLE 10: ANOVA for Performance Appraisal Feedback

\begin{tabular}{|l|l|l|l|l|l|l|}
\hline \multicolumn{2}{|l|}{ Indicator } & Sum of Squares & df & Mean Square & F & Sig. \\
\hline \multirow{3}{*}{1} & Regression & 3.346 & 1 & 3.346 & 3.428 & $.066^{\mathrm{b}}$ \\
\cline { 2 - 8 } & Residual & 133.712 & 137 & .976 & & \\
\cline { 2 - 7 } & Total & $\mathbf{1 3 7 . 0 5 8}$ & $\mathbf{1 3 8}$ & & & \\
\hline
\end{tabular}

a. Dependent Variable: Employee Engagement

b. Predictors: (Constant), Performance Appraisal Feedback

The performance appraisal feedback coefficients are presented in Table 11. To test for the significance of performance appraisal feedback, the regression coefficients $(\beta 2)$, the intercept $(\beta o)$, and the significance of the model were subjected to the t-test to test the null hypothesis that the coefficient is zero. The null hypothesis state that, $\beta$ (beta) $=0$, meaning that there is no significant influence of performance appraisal feedback on employee engagement as the slope $\beta$ (beta) $=0$.

The $Y=\beta_{0}+\beta_{2} X_{2}+\varepsilon$ therefore became Employee Engagement $=1.728+0.144$ (Performance Appraisal Feedback). The results on the beta coefficient of the resulting model showed that the constant alpha $=1.728$ is significantly different from o since the $\mathrm{p}<0.05$. The co- 
efficient $\beta=0.144$ was insignificantly different from $\mathrm{o}$ with a $\mathrm{p}>0.05$. The finding of this study disagreed with the findings of previous studies such as that of Pichler, Beenen and Wood(2018) and Kihama and Wainaina(2019). The findings suggested that one unit change in employee engagement would lead to 0.144 changes in performance appraisal feedback in oil and gas, wire industries, and tertiary institution in South-West Nigeria.

TABLE 11: Regression Coefficients of Performance Appraisal Feedback

\begin{tabular}{|l|l|l|l|l|l|}
\hline Model:1 & $\beta_{\mathrm{i}}$ & Std. Error & Beta & $\mathrm{t}$ & Sig. \\
\hline $\begin{array}{l}\text { (Constant) } \\
\text { Performance Appraisal Feedback }\end{array}$ & 1.728 & .278 & & 6.213 & .000 \\
\cline { 2 - 7 } & .144 & .078 & .156 & 1.852 & .066 \\
\hline
\end{tabular}

Dependent Variable: Employee Engagement

Predictors: (Constant), Performance Appraisal Feedback

Multiple Regression Analysis between Performance Appraisal, Performance Appraisal Feedback, and Employee Engagement

The multiple regression analysis was conducted to empirically determine whether or not performance appraisal and feedback were significant determinants of the employee engagement in oil and gas, wire industries, and tertiary institution in South-West Nigeria.

Therefore, the overall model for the study was as follows:

$$
\begin{aligned}
& \mathrm{EE}=\beta_{\mathrm{o}}+\beta_{1} \mathrm{X}_{1}+\beta_{2} \mathrm{X}_{2}+\varepsilon \\
& \text { Where: } \\
& \mathrm{EE}=\text { Employee engagement } \\
& \mathrm{X}_{1}=\text { Performance Appraisal } \\
& \mathrm{X}_{2}=\text { Performance appraisal feedback } \\
& \varepsilon=\text { Error term }
\end{aligned}
$$

The results in Table 12 showed the relationship $\mathrm{R}=.286$, which indicated a relationship between performance appraisal, performance appraisal feedback and employee engagement in oil and gas, wire industries, and tertiary institution in South-West Nigeria. The adjusted $\mathrm{R}$-squared $=.082$ indicated that $8.2 \%$ of the variation in the employee engagement can be explained by Performance Appraisal, performance appraisal feedback while the remaining can be explained by other variables not captured in this study.

TABLE 12:Overall Summary Model of HRMP

\begin{tabular}{|c|c|c|c|c|}
\hline Model & R & R Square & Adjusted R Square & Std. Error of the Estimate \\
\hline 2 & $.286^{\mathrm{a}}$ & .082 & .068 & 0.96203 \\
\hline
\end{tabular}

a. Predictors: (Constant), Performance Appraisal, Performance Appraisal Feedback

The overall model significance is presented in Table 13. This indicates that the goodness of fit for the regression model between performance appraisal, performance appraisal feedback, and employee engagement. This was supported by a probability value of 0.000 ( $p<0.05)$. The study, therefore, concludes that performance appraisal and feedback would significantly influence employee engagement in oil and gas, wire industries, and tertiary institution in South-West Nigeria. 
TABLE 13: ANOVA Model of Fitness

\begin{tabular}{|c|l|r|r|r|r|r|}
\hline \multicolumn{2}{|l|}{ Indicator } & Sum of Squares & df & Mean Square & F & Sig. \\
\hline \multirow{2}{*}{1} & Regression & 11.189 & 2 & 5.594 & 6.045 & $.003^{\mathrm{b}}$ \\
& Residual & 125.869 & 136 & .926 & \\
& Total & $\mathbf{1 3 7 . 0 5 8}$ & $\mathbf{1 3 8}$ & & & \\
\hline
\end{tabular}

a. Dependent Variable: Employee Engagement

b. Predictors: (Constant), Performance Appraisal, Performance Appraisal Feedback

The coefficients are presented in Table 14. The results show that performance appraisal and feedback was significant to the model $(\mathrm{p}<0.05)$. The $\mathrm{Y}=\beta 0+\beta 1 \mathrm{X} 1+\beta_{2} \mathrm{X}_{2}+\varepsilon$ therefore became Employee Engagement = 0.924+ 0.253 (Performance appraisal) + 0.137 (Performance Appraisal Feedback). From Table14, the constant and performance appraisal feedback was not statistically significant ( $\mathrm{p}>0.05$ ) while performance appraisal was found to be significant $(\mathrm{p}<0.05)$.

TABLE 14: Overall Regression Coefficients of HRMP

\begin{tabular}{|l|l|l|l|l|l|}
\hline Model & $\beta_{\mathrm{i}}$ & Std. Error & Beta & $\mathrm{t}$ & Sig. \\
\hline (Constant) & .924 & .387 & & 2.389 & .018 \\
Performance Appraisal & .253 & .087 & .239 & 2.911 & .004 \\
Performance Appraisal Feedback & .137 & .076 & .148 & 1.806 & .070 \\
\hline
\end{tabular}

Dependent Variable: Employee Engagement

Predictors: Performance appraisal, performance appraisal feedback

Moderating influence of Tenure on the relationship between Performance Appraisal, Performance Appraisal Feedback, and Employee Engagement

The interaction between performance appraisal, performance appraisal, and tenure was calculated. The regression models used are: $\mathrm{EE}=\beta_{\mathrm{o}}+\beta_{1} \mathrm{PA}+\beta_{1} \mathrm{PA} * \mathrm{TENURE}+\mathrm{e}, \mathrm{EE}=\beta_{\mathrm{o}}+\beta_{2} \mathrm{PAF}$ $+\beta_{2} \mathrm{PAF}^{*} \mathrm{TENURE}+\mathrm{e}$. and $\mathrm{EE}=\beta_{\mathrm{o}}+\beta_{1} \mathrm{PA}+\beta_{2} \mathrm{PAF}+\beta_{3} \mathrm{PA}^{*} \mathrm{TENURE}+\beta_{4} \mathrm{PAF}^{*} \mathrm{TENURE}+\mathrm{e}$. The results are presented in Table 15 . Table 15 shows that the value of adjusted R2increased by $1.1 \%, 5.7 \%$ and $0.1 \%$ for performance appraisal, performance appraisal feedback and the multivariate of the two variables respectively when the tenure of the employee was considered. This implies that the tenure of an employee had a moderating effect on the relationship between performance appraisal and performance appraisal feedback and employee engagement.

This is a case of positive enhancement. Given the results, the study found out that tenure of the employee had a moderating influence on the relationship between performance appraisal, performance appraisal feedback and employee engagement in oil and gas, wire industries, and tertiary institution in South-West Nigeria. This is consistent with the report of Blessingwhite (2011) who reported that long-time employees who spent seven years and above are more engaged than new employees. 
TABLE 15: Model Summary of Moderating effect of Tenure on Performance Appraisal and Employee Engagement

\begin{tabular}{|l|l|r|r|r|r|r|r|}
\hline & Model & \multicolumn{1}{|c|}{$\mathrm{R}$} & \multicolumn{1}{c|}{ R quare } & Adj. R quare & SE of the stimate & ANOVA & P-value \\
\hline $\begin{array}{l}\text { Performance } \\
\text { Appraisal }\end{array}$ & $\begin{array}{l}\text { Without } \\
\text { moderator }\end{array}$ & $.244^{\mathrm{a}}$ & .060 & .053 & .96994 & 4.606 & .004 \\
\cline { 2 - 8 } & $\begin{array}{l}\text { With } \\
\text { moderator }\end{array}$ & $.267^{\mathrm{b}}$ & .071 & .058 & .96743 & 5.221 & .007 \\
\hline $\begin{array}{l}\text { Performance } \\
\text { Appraisal } \\
\text { Feedback }\end{array}$ & $\begin{array}{l}\text { Without } \\
\text { moderator }\end{array}$ & $.156^{\mathrm{c}}$ & .024 & .017 & .98793 & 3.428 & .066 \\
\cline { 2 - 8 } & $\begin{array}{l}\text { With } \\
\text { moderator }\end{array}$ & $.284^{\mathrm{d}}$ & .081 & .067 & .96248 & 5.976 & .003 \\
\hline $\begin{array}{l}\text { Performance } \\
\text { appraisal, } \\
\text { Performance } \\
\text { Appraisal } \\
\text { Feedback }\end{array}$ & $\begin{array}{l}\text { Without } \\
\text { moderator }\end{array}$ & $.286^{\mathrm{e}}$ & .082 & .068 & .96203 & 6.045 & .003 \\
\cline { 2 - 8 } & With & $.288^{\mathrm{f}}$ & .083 & .062 & .96502 & 4.058 & .008 \\
\hline
\end{tabular}

Predictors: (Constant), Performance Appraisal Feedback

Predictors: (Constant), Performance Appraisal Feedback, Performance Appraisal Feedback * Gender

Predictors: (Constant), Performance Appraisal

Predictors: (Constant), Performance Appraisal, Performance Appraisal * Gender

Predictors: (Constant), Performance Appraisal, Performance Appraisal Feedback

Predictors: (Constant), Performance Appraisal, Performance Appraisal Feedback, (Performance Appraisal, Performance Appraisal Feedback) * Gender

From Table 15, the p-value for performance appraisal before the introduction of moderating variables is not significant. However, when the tenure was introduced, the model was not only improved, but also the model became significant. This is an indication that employees, especially the older employee in terms of the time they have invested in the organization valued performance appraisal feedback more than the fresher and employees whose tenure was less than five years.

The findings of this study also concurred with the findings of Menguc, Auh, Yeniaras, and Katsikeas (2017) but contradicted the findings of Mustafa et al., (2017) which reported that no significant association was observed between tenure and engagement. The findings of this study also concurred with the report from a survey which revealed that the long-time employees that have spent seven years and above with an organization tend to be more engaged than new employees (Blessingwhite, 2011). It also agreed with the findings of some previous studies (Menguc et al., 2017). However, the findings of the study contradicted the findings of Mustafa et al. (2017).

\section{Conclusion}

The focus of this paper was to investigate whether or not employees' tenure matter in the relationships between performance appraisal, performance appraisal feedback and employee engagement in the oil and gas, wire industries, and tertiary institution in South-West Nigeria. The study concluded that there was performance appraisal practice in oil and gas, wire industries, and tertiary institution in South-West Nigeria. It was also concluded that employee tenure had 
a moderating influence on the relationship between performance appraisal, performance appraisal feedback and employee engagement in the oil and gas, wire industries, and tertiary institution in South-West Nigeria. Based on the findings of this study, the paper recommended that employee characteristics being important factors should be taken into consideration of Human resource practitioners for organization effectiveness and productivity. The paper recommended that HR managers should pay more attention to the employee metrics in implementing HR policies. Researchers and scholars should also explore the employee data, metrics and characteristics in their researches and investigations. This study encountered some limitations which included the tight schedule of respondents which sparingly allow them to attend to questionnaires. This obstacle was overcome by giving them more time to fill the questionnaires. Organisational entry was another limitation which was addressed by using snowballing method of gaining organisational entry. This study obtained sample from South-Western part of Nigeria, future study can draw sample from other geo-political zone of Nigeria to compare the results and advance research in this area of study. The moderating variable in the study was employee tenure, other variables such as leadership style, work environment, trade unionism can be investigated to establish their moderating influence on the relationship between employee performance appraisal and employee engagement.

\section{Conflict of Interest}

No conflict of interest is to be declared in this paper.

\section{References}

Alfes, K., Truss, C., Soane, E. C., Rees, C., \& Gatenby, M. (2013). The relationship between line manager behavior, perceived HRM practices, and individual performance: examining the medicating role of engagement. Human Resource Management, 52(6), 839-859. https://doi.org/10.1002/ hrm.21512

Alzyoud, A. A. (2018). The influence of human resource management practices on employeee work engagement. Foundations of Management, 10(1), 251-256.

Armstrong, M., \& Taylor, S. (2014). Armstrong's handbook of human resource management practice. Kogan Page Publishers.

Babbie, E. R. (2016). The practice of social research (14th ed.). Boston, MA: Cencage Learning.

Bhowal, M., \& Saini, D. (2019). Employee engagement strategies with special focus on Indian firms. In N. Sharma, N. Chaudhary, \& V. K. Singh (Eds.), Management Techniques for Employee Engagement in Contemporary Organizations (pp. 165-179). Hershey, PA: IGI Global.

Blessingwhite. (2011). Employee engagement. Princeton, NJ.

Brown, M., \& Redman, T. (2017). Performance appraisal. In Adrian Wilkinson, T. Redman, \& T. Dundon (Eds.), Contemporary Human Resource Management: Texts and cases (5th ed., pp. 189210). Pearson.

Brunetto, Y., Xerri, M., Farr-Wharton, R., Shacklock, K., Newman, S., \& Dienger, J. (2013). The impact of workplace relationships on engagement, well-being, commitment and turnover for nurses in Australia and the USA. Journal of Advanced Nursing, 69(12), 2786-2799. https://doi.org/doi. org/10.1111/jan.12165

Daniels, J. R. (2016). An exploratory comparative case study of employee engagement. Christian High- 
er Education, 15(3), 126-139.

Dessler, G. (2013). Human Resource Management (15th ed.). New York, NY: Pearson.

Fajana, S. (2009). HR management in Africa: The social and economic framework. Personalfuhrung, $7(1), 80-86$.

Gallup. (2018). Trends in global engagement. London.

Hassan, A. (2007). Human resource development and organizational values. Journal of European Industrial Training, 31(6), 435-448.

Hughes, C. (2018). Ethical and Legal Issues in Human Resource Development: Evolving roles and emerging trends. Switzerland: Palgrave Macmillan.

Imperatori, B. (2017). Engagement and Disengagement at Work: Drivers and Organisational Practices to Sustain Employee Passion and Performance. Swittzerland: Springer.Book

Izuogu, S. A. (2015). Impact of organisational culture on recruitment and selection practices in the oil andn gas construction industry in Nigeria: Saipem in focus. European Scientific Journal, 11(16), 161-172.

Jani, H., \& Balyan, R. K. (2016). Impact of employee perceived HR practices on employee engagement. Journal of Business Management \& Social Sciences Research, 5(9), 258-261.

Jung, H. S., Yoon, H. S., \& Yoon, H. H. (2018). The effects of diversity management in a deluxe hotel on F \& B employees' job engagement and organisational commitment. Korean Journal Food Cook Science., 32(3), 363-369.

Kihama, J. W., \& Wainaina, L. (2019). Performance appraisal feedback and employee productivity in water sewage companies in Kiambu County, Kenya. International Academic Journal of Huma Resource and Business Administration, 3(5), 376-393.

Laba, K., \& Geldenhuys, M. (2016). Psychological availability and work engagement: The moderating role of sex and race. Journal of Psychology in Africa, 26(2), 107-112.

Li, X., \& Frenkel, S. (2017). Where hukou status matters : analyzing the linkage between supervisor perceptions of HR practices and employee work engagement. The International Journal of Human Resource Management,28(17), 2375-2402. https://doi.org/10.1080/09585192.2015.1137613

Lunenburg, F. C. (2011). Expectancy thoery of motivation: motivating by altering expectations. International Journal of Management, Business, and Administration, 15(1), 1-6.

Mamoria, C. B., \& Rao, V. S. P. (2014). Personnel Management (31st ed.). Mumbai: Himalaya Publishing House PVT. Ltd.

Menguc, B., Auh, S., Yeniaras, V., \& Katsikeas, C. S. (2017). The role of climate: implications for service employee engagement ad customer service performance. Journal of the Academy of Marketing Science, 45(3), 428-451.

Mondy, R. W., \& Martocchio, J. J. (2016). Human Resource Management (14th ed.). Harlow, UK: Pearson.

Mugenda, O. M., \& Mugenda, A. G. (2012). Research methods dictionary. Retrieved from http://ir-library.ku.ac.ke/handle/123456789/8329

Mugesani, P. A. (2018). Role of corporate social responsibility activities on employees' commitment to firms listed at Nairobi Stock Exchange in Kenya. Nairobi, Kenya.

Mustafa, G., Bilal, A. R., Mahmood, B., \& Murtaza, G. (2017). Motivation enhancing HRM practices and employee demographics on affective commitment among employees in textile manufacturing in Pakistan. Pakistan Business Review, 18(4), 865-886.

Nel, J. H., \& Linde, B. (2019). The art of engaging unionised employees. Singapore: Palgrave Macmillan.

Noe, R. A. (2017). Employee Training and Development (7th ed.). New York, NY: McGraw Hill. 
Noe, R. A., Hollenbeck, J. R., Gerhart, B., \& Wright, P. M. (2016). Fundamentals of Human Resource Management (6th ed.). New York, NY: McGraw Hill.

Pichler, S., Beenen, G., \& Wood, S. (2018). Feedback frequency and appraisal reactions: a meta-analytic test of moderators. The International Journal of Human Resource Management, 1-26. https:// doi.org/10.1080/09585192.2018.1443961

Rana, S., \& Chopra, P. (2019). Developing and Sustaining Employee Engagement: The Strategic Perspective in Telecom Company. In N. Sharma, N. Chaudhary, \& V. Singh (Eds.), Management Techniques for Employee Engagement in Contemporary Organizations (pp. 142-164). Hershey, PA: IGI Global.

Salaman, G., Storey, J., \& Billsberry, J. (2005). Strategic human resource management: defining the field. Strategic Human Resource Management, 1-11.

Schaufeli, W. B., Bakker, A. B., \& Salanova, M. (2006). The measurement of work engagement with a short questionnaire: A cross-national study. Educational and psychological measurement, 66(4), 701-716.

Shin, S. J., Jeong, I., \& Bae, J. (2018). Do high-involvement HRM practices matter for worker creativity? A cross-level approach. The International Journal of Human Resource Management, 29(2), 260-285.

Shuck, B., Reio, T. G., \& Rocco, T. S. (2011). Employee engagement: an examination of antecedent and outcome variables. Human Resource Development International, 14(4), 427-445. https://doi. org/10.1080/13678868.2011.601587

Torrington, D., Hall, L., Taylor, S., \& Atkinson, C. (2017). Human Resource Management (1oth ed.). Harlow, UK: Pearson.

Turner, J. C., \& Reynolds, K. J. (2010). The story of social identity. In T. Postmes \& N. Branscombe (Eds.), Rediscovering Social Identity: Core Sources. Oxford: Psychology Press.

Vroom, V. (1964). Expectancy Theory. New Dehli, India: New Age International.

Wilkinson, A., Redman, T., \& Dundon, T. (2017). Human Resource Management: A contemporary Perspective. In A. Wilkinson, T. Redman, \& T. Dundon (Eds.), Contemporary Human Resource Management: Texts and cases (5th ed., pp. 4-33). Harlow: Pearson. 